\title{
User's Guide for Waste Tank Corrosion Data Model Code
}

\author{
D. B. Mackey \\ J. R. Divine
}

December 1986

Prepared for the U.S. Department of Energy under Contract DE-AC06-76RLO 1830

Pacific Northwest Laboratory Operated for the U.S. Department of Energy by Battelle Memorial Institute 


\title{
DISCLAIMER
}

This report was prepared as an account of work sponsored by an agency of the United States Government. Neither the United States Government nor any agency thereof, nor Battelle Memorial Institute, nor any of their employees, makes any warranty, expressed or implied, or assumes any legal liability or responsibility for the accuracy, completeness, or usefulness of any information, apparatus, product, or process disclosed, or represents that its use would not infringe privately owned rights. Reference herein to any specific commercial product, process, or service by trade name, trademark, manufacturer, or otherwise, does not necessarily constitute or imply its endorsement, recommendation, or favoring by the United States Government of any agency thereof, or Battelle Memorial Institute. The views and opinions of authors expressed herein do not necessarly state or reflect those of the United States Government or any agency thereof, or Battelle Memorial Institute.

\author{
PACIFIC NORTHWEST LABORATORY \\ operated by \\ BATTELLE \\ for the \\ UNITED STATES DEPARTMENT OF ENERGY \\ under Contract DE-AC06-76RLO 1830
}

\begin{tabular}{|c|c|}
\hline \multirow{2}{*}{\multicolumn{2}{|c|}{ Printed in the United States of America }} \\
\hline & \\
\hline \multirow{2}{*}{\multicolumn{2}{|c|}{$\begin{array}{l}\text { National Technical Information Service } \\
\text { United States Department of Commerce }\end{array}$}} \\
\hline & \\
\hline \multicolumn{2}{|c|}{5285 Port Royal Road } \\
\hline \multicolumn{2}{|c|}{ Spring field, Virginia 22161} \\
\hline \multirow{2}{*}{\multicolumn{2}{|c|}{$\begin{array}{l}\text { NTIS Price Codes } \\
\text { Microfiche A01 }\end{array}$}} \\
\hline & \\
\hline \multicolumn{2}{|c|}{ Printed Copy } \\
\hline & Price \\
\hline Pages & Codes \\
\hline $001-025$ & $\mathrm{~A} 02$ \\
\hline $026-050$ & $\mathrm{~A} 03$ \\
\hline $051-075$ & $\mathrm{~A} 04$ \\
\hline $076-100$ & A05 \\
\hline $101-125$ & A06 \\
\hline $126-150$ & A07 \\
\hline $151-175$ & A08 \\
\hline $176-200$ & A09 \\
\hline 201-225 & A010 \\
\hline 226-250 & A011 \\
\hline $251-275$ & A012 \\
\hline $276-300$ & A013 \\
\hline
\end{tabular}


USER'S GUIDE FOR WASTE TANK

CORROSION DATA MODEL CODE

D. B. Mackey

J. R. Divine

December 1986

Prepared for the U.S. Department of Energy under Contract DE-AC06-76RLO 1830

Pacific Northwest Laboratory

Richland, Washington 99352 


\section{ACKNOWLEDGMENTS}

The contribution of $D$. J. Bates and W. M. Bowen to the program and the report are gratefully acknowledged. 
• 


\section{ABSTRACT}

Corrosion tests were conducted on A-516 and A-537 carbon steel in simulated Double Shell Siurry, Future PUREX, and Hanford Facilities wastes. The corrosion rate data, gathered between 25 and $180^{\circ} \mathrm{C}$, were statistically "modeled" for each waste; a fourth model was developed that utilized the combined data.

The report briefly describes the modeling procedure and details on how to access information through a computerized data system. Copies of the report and operating information may be obtained from the author (DB Mackey) at 509-376-9844 or FTS 444-9844. 


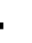

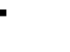




\section{CONTENTS}

ACKNOWLEDGMENTS. $. \quad . \quad . \quad . \quad . \quad . \quad . \quad . \quad . \quad . \quad i j i$

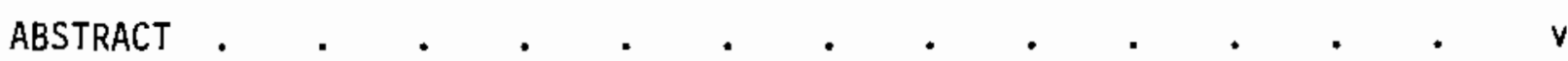

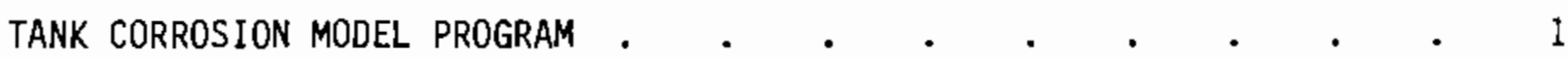

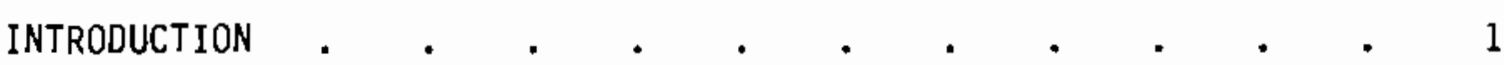

Hypothesized Model Form . . . . . . . . . . . 5

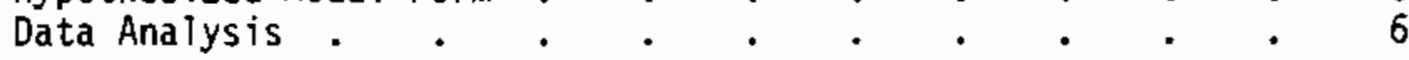

INTERPRETING THE FITTED MODELS. • • • . • • • . 8

A COMPUTER PROGRAM FOR PREDICTING CORROSION RATES . . . . . . . 11

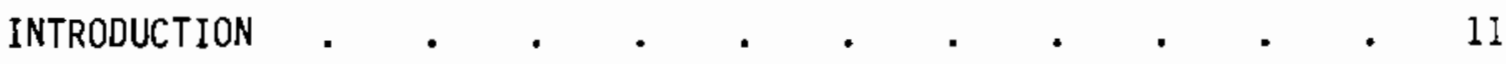

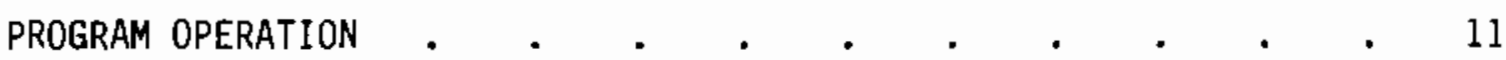

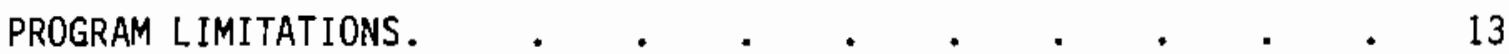

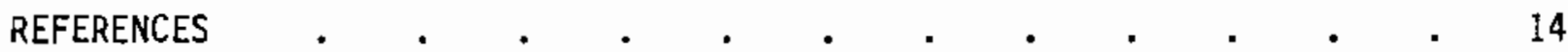




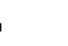




\section{TANK CORROSION MODEL PROGRAM}

INTRODUCTION

Corrosion tests of tank construction material in support of construction and operation of double shell waste storage tanks at Hanford were initiated over the range of compositions and temperatures expected during waste storage. The major emphasis was placed on temperatures at or below $100^{\circ} \mathrm{C}$ because that was the primary operating range. However, tests up to at least $177^{\circ} \mathrm{C}$ were performed because that was the nominal design temperature at which corrosion rates were not to exceed one mil per year.

The experimental data were analyzed and used to generate "models." The models are statistical in nature with no attempt to describe the physical interaction. (1)

This report briefly describes how the prediction models were set up and how to access the computer code used in conjunction with the corrosion rate prediction model. The models include the A-516 alloy steel used in the older single shell tanks as well as the A-537 alloy steel used currently on double shell tanks. Three types of wastes are modeled separately using different compositions and ranges of compositions to simulate Double Shell Slurry waste, Future PUREX waste, and Hanford Facjlities waste, as shown in Tables 1 to 3 . A fourth comprehensive model was developed using the combined corrosion data collected for each of the above types of waste.

This code was developed by the staff of Pacific Northwest Laboratory's (PNL) Statistics Section based on corrosion tests conducted for Rockwell Hanford and the U.S. Department of Energy High-Level Waste Program by the Corrosion Research and Engineering Section of PNL. The models were constructed based on a computer-aided designed regression experiment using a matrix of wejght-loss data (converted to corrosion rates) generated as a function of a series of tank waste compositions.

The program and data are available on a Hewlett-Packard 100D minicomputer; a minimum knowledge of $\mathrm{H}_{\text {-P's }} \mathrm{RTE}$ 6/VM operating system is necessary to access the program. Presently a program called TNFIN is the only program available from a remote terminal, and its output is in tabular form. 
TABLE 1. Double Shell Slurry Composition Range

\begin{tabular}{|c|c|}
\hline & $\begin{array}{l}\text { COMPOSITION } \\
\text { Range (MOLARITY) } \\
\text { Low - High } \\
\end{array}$ \\
\hline $\mathrm{OH}^{-}$ & $0.5-10.0$ \\
\hline $\mathrm{NO}_{3}^{-}$ & $1.0-8.0$ \\
\hline $\mathrm{NO}_{2}^{-}$ & $0.2-10.0$ \\
\hline $\mathrm{A} 10_{2}^{-}$ & $0.0-5.0$ \\
\hline $\mathrm{CO}_{3}^{-}$(2 fixed values) & 0.2 or 0.25 \\
\hline $\mathrm{PO}_{4}^{\bar{\Xi}}$ & $0.0-2.0$ \\
\hline EDTA/HEDTA & $0.0-1.0$ \\
\hline Citrate ( 3 fixed values) & $0.0,0.2$, or 0.6 \\
\hline $\mathrm{SO}_{4}=$ & 0.05 \\
\hline
\end{tabular}

TABLE 2. Range of Composition of Future PUREX Waste

\begin{tabular}{|c|c|c|c|c|c|c|c|c|c|}
\hline Waste & $\mathrm{OH}^{-}$ & $\underline{\mathrm{AT}}{ }^{\mathrm{a}}$ & $\mathrm{NO}^{-}$ & $\mathrm{NO}_{2}^{-}$ & $\mathrm{CO}_{3}^{=}$ & $\underline{\mathrm{SO}_{4}^{2}}$ & $\mathrm{Cit}^{\mathrm{Eb}}$ & $\mathrm{F}^{-}$ & $\underline{\mathrm{k}^{+}}$ \\
\hline PUREX SIUdge & $.2-.8$ & - & $.01-.05$ & $.01-.05$ & $.01-.05$ & $s$ & - & $1-1.5$ & $2-.5$ \\
\hline Declad. Slurry & $3 .-8$ & + & $.2-.5$ & - & s & $s$ & - & $s(<1)$. & $2 .-3$ \\
\hline CAW (Opt. A) & $3 .-.8$ & - & $.2-.5$ & - & $s$ & s & - & $.1-.2$ & - \\
\hline CAW (Opt. B) & $.001-.1$ & $.5-1$ & $3 .-5$ & $1 .-2$. & - & $\mathrm{s}$ & $1 .-2$ & $.15-.3$ & - \\
\hline CAW (Opt. C) & $.5-1$ & $.5-.1$ & $3 .-5$ & $1 .-2$ & $s$ & $s$ & - & $.15-.3$ & - \\
\hline
\end{tabular}




$\begin{array}{lc}\text { TABLE 3. } & \begin{array}{l}\text { Hanford Facilities Waste } \\ \text { Composition Range }\end{array} \\ & 0.0001-2 \mathrm{M} \\ \mathrm{OH}^{-} & 0-0.01 \\ \mathrm{NO}_{2}^{-} & 0-5 \\ \mathrm{PO}_{4}^{\equiv} & 0-2.9 \\ \mathrm{SO}_{4}^{\equiv} & \end{array}$

The three dimensional plots like the example shown in Figure 1 are based on the regression model. The plotting programs using the regression models currently are only available using the graphics terminals that are connected directly to the minicomputer.

For future use, the actual weight-loss data for the coupons are also stored on the computer utilizing H-P's "IMAGE" Oatabase Management System. The design of the matrix for the tests, because of the number of possible input variables, produces a sparsely populated matrix of data. There has been no effort to date to graph the test results directly from the data base. As the system is expanded in the future, these data and other corrosion data may be used to form a more generalized corrosion data base.

The use of computer-aided design techniques for regression experiments is a significant advance over the more restrictive classical experimental designs (for example, factorial designs and special purpose response surface designs). The AODEXC computer program at PNL incorporates the methods described by Wynn ${ }^{(2)}$ and St. John and Draper ${ }^{(3)}$ for constructing optimal regression experimental designs. This is especially useful in designing corrosion experiments, where solubilities or other factors require the use of variable composition levels.

Because the range of concentrations of each chemical is continuous, the number of possible compositions is infinite. The classical factorial design approach would be to define three concentration levels (low, medium, and high concentrations) for each minor chemical. With five chemicals at three levels and three chemicals at two levels, the number of possible compositions is $3^{5} \cdot 2^{3}=1944$. However, because a polynomial equation can be written to represent the data, it is not necessary to include all 1944 compositions in 


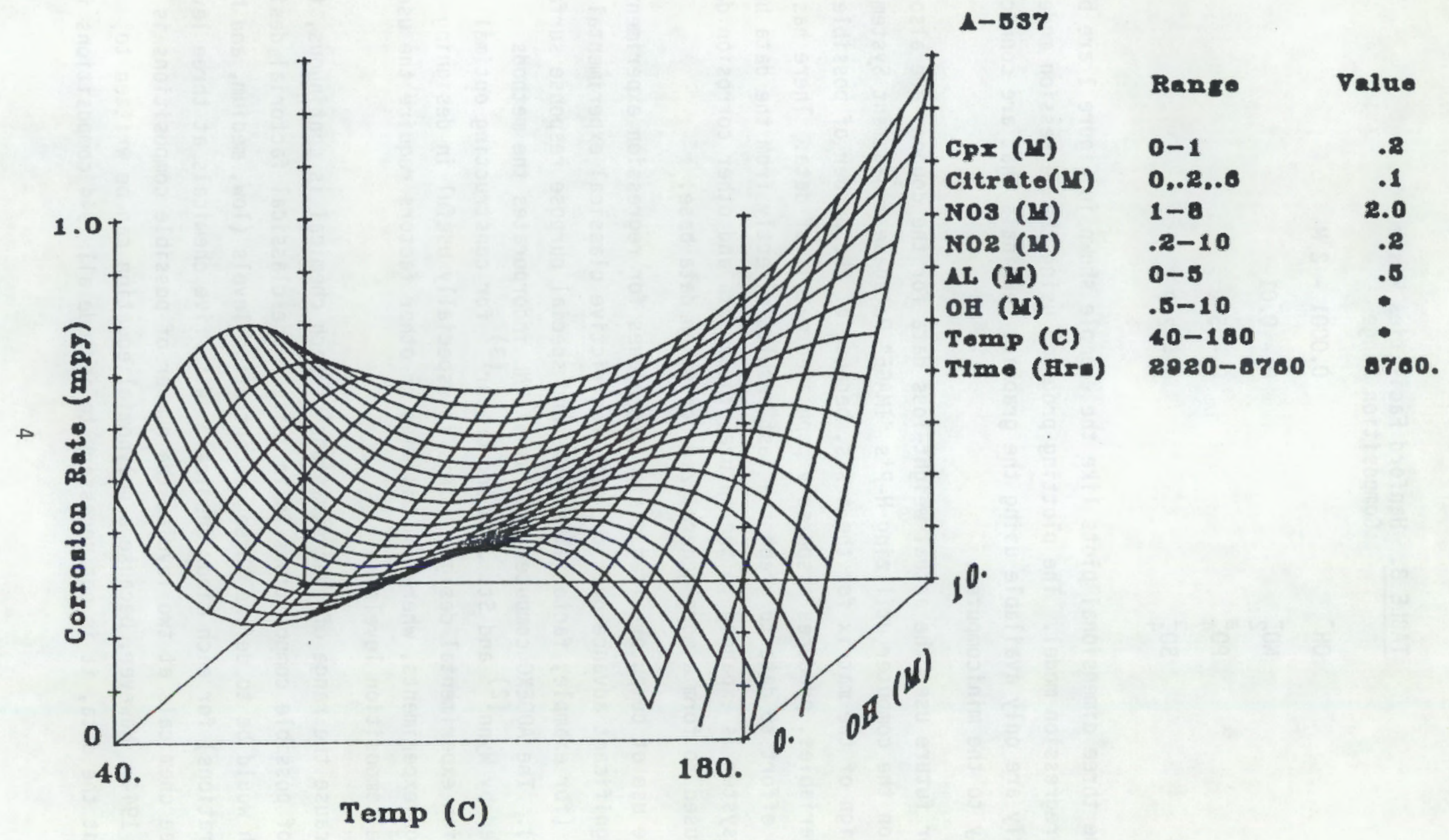

FIGURE 1. Double Shell Slurry Predictor Model 
the study. Also, practical considerations such as available facilities, manpower, time and budget dictated an upper limit of 40 compositions. Hypothesized Model Form

For the construction of a computer-aided environmental design, a hypothesized prediction model with unknown parameters corresponding to "major" and "minor" chemicals is required. The major chemicals are those which are expected to influence the corrosion rate. The effective concentration levels of the major chemicals appear in the hypothesized model as linear (or first order) terms, quadratic (or second order) terms, and mixed quadratic terms (products of all possible pairs). The minor chemicals are expected to have little or no effect on the corrosion rate. The effective concentration levels of the minor chemicals appear in the hypothesized model only as linear terms.

The Future PUREX (FP) waste is used as an example of the design process. For the FP waste, there are five major chemicals and three minor chemicals. Thus, the hypothesized polynominal model for a specified composition is given by

$$
y+a+\sum_{i=1}^{8} b_{i} x_{i}+\sum_{i=1}^{5} c_{i} x_{i}^{2}+\sum_{j=1}^{5} d_{j<i} x_{j} x_{j}+e,
$$

where:

- $y$ is the measured value of the corrosion indicator (e.g., corrosion rate in mils/year) for a specified composition,

- $x_{1}, x_{2}, \ldots, x_{5}$ are the effective concentration levels of the major chemicals,

- $x_{6}, x_{7}, x_{8}$ are the effective concentration levels of the minor chemicals,

- $s, b_{j}, c_{i}$, and $d_{i j}$ are 24 unknown constants (parameters) that will be estimated from the experimental data,

- $e$ is a random component due to the nonreproducibility of $y$ when replicate experiments are performed using a specified composition. Details of this model and justification for its use have been given previously. (1) 
Data Analysis

Prior to actual model development, the data were transformed and coded based on observed corrosion rates (expressed as mils/year [mpy]) of the form

$$
\operatorname{lnmpy}=\ln (\mathrm{mpy}+1.25)
$$

The natural log transformation is a variance stabilizing procedure that was deemed necessary for this data due to an observed increase in corrosion variability with increased corrosion rates. The modeling procedure assumes that the variability in corrosion rates is approximately constant over all test conditions. The addition of 1.25 made $a 11$ transformed values greater than zero.

The chemical compositions were coded by subtracting the approximate mid-range of the levels that occurred in the tests from each value and dividing by approximately one-half of the range. This helps protect against computer round-off error which can be a significant problem, especially with a data base of this size, the range of compositions that were used, and the use of polynomial models that require many multiplications. The resulting coded values are basically in the interval of -1 to 1 . For the unified model, the actual codings for each composition are:

$$
\begin{aligned}
& \mathrm{c} 0=\left(\log _{10}(\mathrm{OH})+1\right) / 3 \\
& \mathrm{c1}-(\mathrm{AI}-1.8) / 1.8 \\
& \mathrm{c} 2=\left(\mathrm{NO}_{3}-3.75\right) / 3.75 \\
& \mathrm{c} 3=\left(\mathrm{NO}_{2}-4\right) / 4 \\
& \mathrm{c} 4=(\mathrm{Complex}-.5) / .5 \\
& \mathrm{c5}=(\mathrm{F}-.5) / .5 \\
& \mathrm{C}=\left(\mathrm{CO}_{3}-.1\right) / .1 \\
& \mathrm{c}=\left(\mathrm{PO}_{4}-2.5\right) / 2.5 \\
& \mathrm{C} 8=\left(\mathrm{SO}_{4}-1.5\right) / 1.5 \\
& \mathrm{c} 9=(\mathrm{Citrate}-1) .
\end{aligned}
$$


Exposure temperature and hours of exposure were aiso coded so that the values have minimum and maximum of approximately -1 and 1 , respectively. The codings for the unified models are:

$$
\begin{aligned}
& \mathrm{t} 1=(\text { Temperature }-100) / 75 \\
& \mathrm{hl}=(\text { Hours }-5800) / 3000 .
\end{aligned}
$$

Because some chemical constituents did not appear in each waste type, it was not possible to use every cross product term in the model.

If a particular chemical constituent did not appear in the compositions for a particular waste type, it was given a value of zero prior to coding for all data of that waste type.

The initial polynomial model consisted of the following 372 terms:

- Intercept - 1 term

- Chemical Composition Terms - 30 terms:

$$
\begin{array}{r}
\text { Simple Linear Terms - } c 0 c 1 c 2 c 3 c 4 c 5 c 6 c 7 c 8 c 9-10 \text { terms } \\
\text { Pure Quadratic Terms - } c 0 c 0 c 1 c 1 c 2 c 2 c 3 c 3 c 4 c 4 c 5 c 5-6 \text { terms } \\
\text { (considered to be major constituents) } \\
\text { Cross Product Terms - } c 0 c 1 c 0 c 2 c 0 c 3 c 0 c 4 c 0 c 5-14 \text { terms } \\
c 1 c 2 c 1 c 3 c 1 c 4 c 1 c 5 \\
c 2 c 3 c 2 c 4 c 2 c 5 \\
c 3 c 4 c 3 c 5
\end{array}
$$

[Complex(c4) and $F(c 5)$ never occurred together]

- Temperature and Time Terms - 11 terms:

Simple Linear Terms - tl hl - 2 terms

Pure Quadratic Terms - h2 t2 t3 - 3 terms

Cross Product Terms - t1h1 t2h1 t3h1 thh2 t2h2 t2h3 - 6 terms

- Cross Products of Composition With Temperature and Time - 330 terms:

Each of the 30 chemical composition terms multiplied by each of the 11 temperature and time terms. 
A model with so many terms in it can be expected to include some that do not add significant information and could be discarded without degrading the predictive capability of the equation; that is, a smaller subset of terms is probably adequate. To select an adequate subset of the terms, a stepwise regression procedure was used. The BMDP Statistical Software Program P2R Stepwise Regression with the FSWAP option was used for this purpose. In this procedure, two options were set which control the program's progress. One is F-to-enter which defines the minimum F-statistic a term must have to enter into the model, while F-to-remove defines the minimum F-statistic a term must maintain to remain in the model. For these models, F-to-enter and F-to-remove, both were set at 1 , which is approximately equal to a significance level of 0.25 . The stepwise program then proceeds by selecting the term, not already in the model, that has the highest F-statistic and meets the F-toenter criteria. Because many of the terms are correlated, adding a term to the model changes the F-statistic for each of the terms already in the model. The program then removes the term in the model with the lowest F-statistic if it does not meet the $F$-to-remove criteria; this is repeated until all "nonsignificant" terms are removed from the model. The program then repeats all of these steps until all terms that meet the criteria to enter the model have been entered.

This procedure was applied separately to each of the alloys. For example, for the A-537 data, a model with 75 terms was chosen with an $R^{2}$ value of $0.56\left(R^{2}\right.$ is the percent of the variability in the observed corrosion rates accounted for by the selected model). Similar techniques were applied to the individual waste types to generate specific models for each. (1)

The equation generated for the A-537 alloy is given in Table 4 . Equations for other models are similar but have more or fewer terms than this.

\section{INTERPRETING THE FITTED MODELS}

Several precautionary statements need to be made about attempts to interpret the values of coefficients for terms in the models. First, most of the boundaries of the experimental region are detemined by limitations on the "nominal" levels of the ten anions in a chemical solution. That is, because of solubilities and saturation, some of the anions which may be added 
TABLE 4. Prediction Equation for the Unified Model for A-537

\begin{tabular}{|c|c|c|c|}
\hline $\ln (m p y+1.25)=$ & 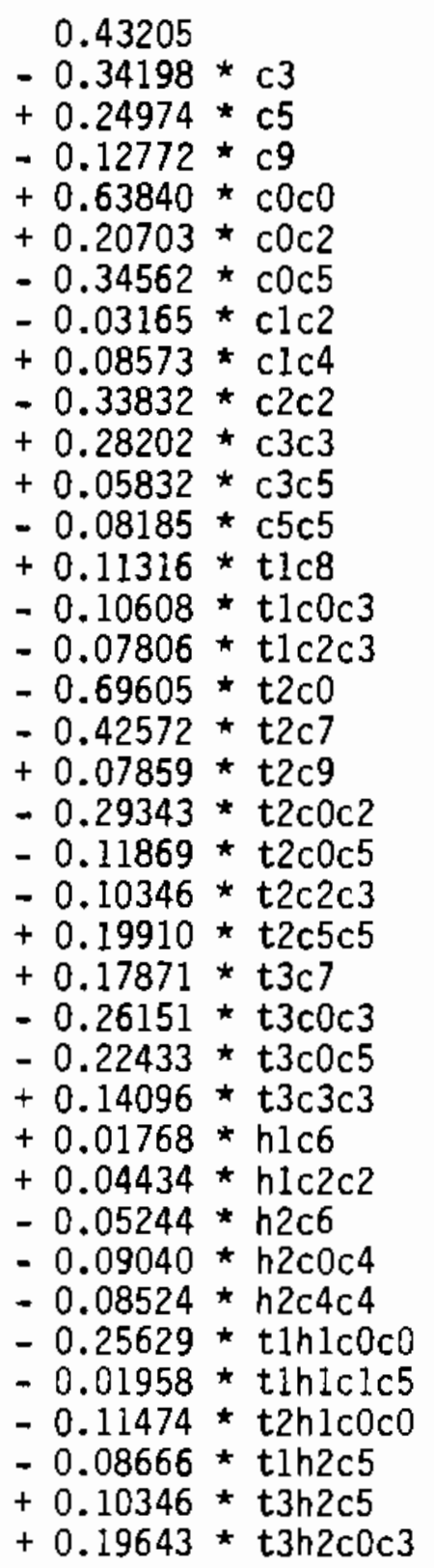 & $\begin{array}{l}+0.55970 \\
+0.18315 \\
+0.11096 \\
+0.30340 \\
=0.67956 \\
+1.31491 \\
+0.12923 \\
-0.16298 \\
+0.13896 \\
+0.31082 \\
+0.07159 \\
+0.11298 \\
-0.43004 \\
+0.69320 \\
-0.06173 \\
-0.13423 \\
+0.42856 \\
+0.22014 \\
+0.16308 \\
-1.00524 \\
+0.25478 \\
-0.13387 \\
-0.08787 \\
+0.09917 \\
-0.13895 \\
+0.21617 \\
-0.12292 \\
-0.11417 \\
-0.03892 \\
-0.08303 \\
+0.04020 \\
+0.03395 \\
+0.03848 \\
+0.04262 \\
-0.02753 \\
-0.05076 \\
-0.15302 \\
-0.26171\end{array}$ & 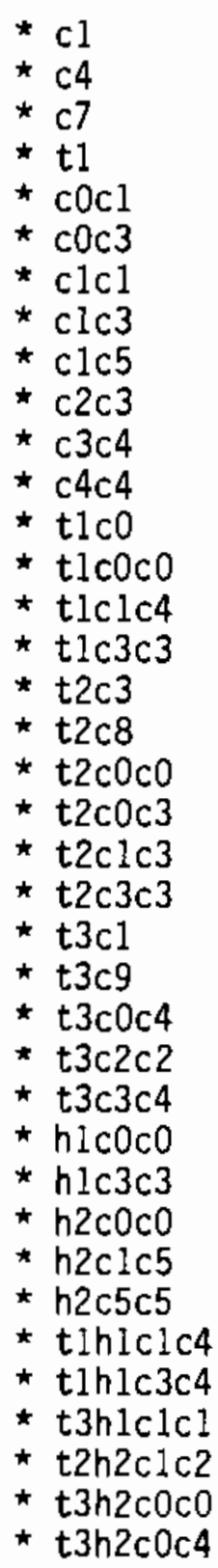 \\
\hline
\end{tabular}


to a solution at their highest levels may be effective at much lower levels due to the presence of other components at high or low levels. These relationships were taken into account in designing the experiments for each one of the waste types and the chemical compositions which are included in each experiment are specified in terms of the "nominal" levels of the anions. Second, all terms appear as coded values and not as raw values. Third, and most important, the reader should be aware of the correlations among the terms in the predictor equations and the effect this has on interpretation. Although the fitted models provided in this report will produce reasonabiy good predictions of corrosion rates in their respective experimental regions, the values of the individual estimated coefficients should not be used to infer the effect or importance of the corresponding terms relative to the corrosion rate. The primary use of these models is for predicting corrosion rates and not for corrosion process modeling. 


\section{A COMPUTER PROGRAM FOR PREDICTING CORROSION RATES}

INTRODUCTION

The fitted models developed for predicting corrosion rates have been incorporated into an interactive computer program which is the subject of this report. The program requests the user to state the alloy, waste type, exposure time, temperature, and the chemical constituents appropriate to the selected waste type. It then utilizes the fitted models to predict the average corrosion rate, in mpy, that would be expected to occur under the specific conditions. The program also computes an estimate of the standard deviation of the predicted value. The program uses these results to compute upper confidence limits for the true average corrosion rate for that set of conditions at the 90,95 , and $99 \%$ confidence levels. It also computes upper $90 / 90,95 / 90$ and $99 / 90$ tolerance limits for the average corrosion rates expected to occur in repeated experiments under this set of conditions. For example, an upper $95 / 90$ tolerance limit indicates that we are $95 \%$ confident that $90 \%$ of average corrosion rates observed under this set of conditions will fall below the limit. The FORTRAN code for the program is not presented in this report but is available from the authors either on tape or as a hard-copy listing.

\section{PROGRAM OPERATION}

Logging in remotely requires a terminal or another computer using a terminal emulator program and a suitable modem. The H-P computers use the Enquire/Acknowledge handshake protocol rather than the more conmon DEC usage of Xon/Xoff (OC1/DC3) protocol. When you dial the number for the H-P computer, the computer will adjust its baud rate to yours (300 or 1200 baud), and when the connection is complete, if you press any key, the computer will respond with a $\log$-in prompt.

Logging in on an H-P computer system is similar to logging into any multiuser system. After establishing a connection, the system prompts with a 
"PLEASE LOG ON" prompt and the user types in his ID using the following format:

$x x x x \cdot z z z z$

where:

$X X X X$ is the user account name and $z z z z$ is a group descriptor.

The computer phone number, account name, group descriptor, and password may be obtained from the first author on 376-9844.

If the ID is valid, the system will prompt "PASSWORD?" and read the user's password without echoing the password back to the user's termina?. An example of a valid log-in would be as follows:

PLEASE LOG-ON: User, General (return)

PASSWORD? $x y z$ (return)

(xyz would not appear on the screen for security reasons.)

With a successful log-in, the system will print some log-in information followed by a welcome message with any current messages of importance to the user. The Tank Model Corrosion Program "TNFIN" will be automatically started and will display the following menu:

ENTER WHICH WASTE MODEL TO USE

1--DOUBLE SHELL SLURRY

2--FUTURE PUREX

\section{3--CUSTOMER WASTE}

4--ALL OF THEM TOGETHER (COMBINED MODEL).

Enter number of desired waste model (followed by return key) to start the program.

The program will now prompt you for the input variables (alloy, time, temperature) and chemical concentrations. After completing the input, the program will print out a list of the variables. There will be a delay of up to several minutes while the computer solves the mathematical model and displays the complete output. 
At this time the program prompts:

IS THERE ANOTHER RUN TO BE PERFORMED? Y/N.

If the answer is "Y" the program will start over with the request for new inputs. If the answer is " $N$ " the program will end but you will still be logged onto the computer. Your current line will start with a ":" followed by a blinking curser, and, if you press any key, the computer will display the following message:

WAITING FOR INPUT

: (blinking curser)

If, at this time, you type

$E X, R P,, K I$ (return)

you will be logged off the system and some pertinent information about your session will be displayed. You will remain connected to the H-P system modem until you hang up your modem.

If you are in a hurry you can hang up your modem and the system will automatically log you off.

PROGRAM LIMITATIONS

This program employs very limited error trapping, and it is very easy to abort the program. When this happens the program can be restarted by typing the program name (TNFIN) when there is a system prompt displayed on the screen, (:), a colon followed by a blinking cursor. Sometimes while the program is running and waiting for an input, if a key is struck twice the computer system will respond with a ( $S=50$ COMMAND ?) prompt, which is a system break-mode query and you can nomally recover by pressing the return key. 


\section{.




\section{REFERENCES}

1. Divine, J. R., H. M. Bowen, D. B. Mackey, D. J. Bates, and K. H. Pool. 1985. Prediction Equations for Corrosion Rates of A-537 and A-516 Steels in Double ShelT Slurry, Future PUREX and Hanford Facilities Wastes. PNL-5488. Pacjfic Northwest Laboratory, Richland, Washington.

2. Wynn, H. P. 1970. "The Sequential Generation of D-0ptimum Experimental Designs." Annals of Mathematical Statistics 41:1655-1664.

3. St. John, R. C., and N. R. Draper. 1975. "D-Optimality for Regression Designs: A Review." Technometrics 17:15-23. 


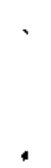


DISTRIBUTION

No. of

Copies

OFFSITE

30 DOE Technical Information Center

5 Geologic Repository Division DOE Office of Civilian Radioactive Waste Management Forrestal Bujlding Washington, DC 20585

ATTN: J. W. Bennett, RH-20

C. R. Cooley, RH-4

M. W. Frei

B. C. Rusche, RH-1

R. Stein, RW-23

3 DOE Office of Defense Waste \& GTN

Washington, DC 20545

ATTN: G. H. Daly, DP-123

J. E. Lytle, $D P-12$

T. C. Chee, DP-123

R. B. Hindman, DP-12

7 DOE Office of Terminal Waste

Disposal \& Remedial Action GTN

Washington, DC 20545

ATTN: J. E. Baublitz, NE-24

J. A. Coleman, NE-25

T. W. McIntosh, NE-25

D. J. McGoff, NE-23

W. R. Voigt, $N E-20$

H. F. Walter, NE-25

Z. B. Zorn, NE-25

M. J. Bell

Oivision of Nuclear Materials

Safety \& Safeguards

Mail Station 881-SS

Nuclear Regulatory Commission

Washington, DC 20555
No. of

Copies

A. T. Clark

Division of Fuel Material Safety

Nuclear Regulatory Commission

Washington, DC 20555

W. J. Dircks

Office of the Executive Director for Operations

Majl Station 6209

Nuclear Regulatory Commission

Washington, DC 20555

2 Environmental Protection Agency

Office of Radiation Programs

401 M Street, S.W.

Washington, DC 20460

ATTN:

D. Egan

G. L. Sjoblom

3 DOE ATbuquerque Operations Office

P.0. Box 5400

Albuquerque, NM 87185

ATTN: K. A. Carlson

M. H. McFadden

J. McGough

H. H. Hannum

DOE West Valley Operations Office

P.0. Box 191

West Vailey, NY 14171

2 OOE Idaho Operations Office

550 Second Street

Idaho Falls, ID 83401

ATTN: J. D. Hamric

J. B. Whitsett

M. J. Barainca

L. Lannj

DOE San Francisco Operations

1333 Broadway

Oakland, CA 94612 
No. of

Copies

M. R. Jugan

DOE Oak Ridge Operations Office P.O. Box E

Oak Ridge, TN 37830

\author{
S. A. Mann \\ DOE Chicago Operations Office \\ 9800 South Cass Avenue \\ Argonne, IL 60439
}

J. 0. Neff

DOE National Waste Program Office

$505 \mathrm{King}$ Avenue

Columbus, OH 43201

W. Cornman

Savannah River Laboratory

Aiken, SC 29801

G. K. Oerte]

DOE Savannah River Operations Office

P.0. Box A

Aiken, SC 29801

D. L. Vieth

DOE Nevada Operations Office

P.0. Box 14100

Las Vegas, NV 89114

2 Argonne National Laboratory

9700 South Cass Avenue

Argonne, IL 60439

ATTN: C. S. Abrams/J. H. Kittel

M. J. Steindler/ L. E. Trevorrow

W. Newcomb

Battelle Memorial Institute

Office of Crystalline Repository Development

9800 South Cass Avenue

Argonne, IL 60439
No. of

Copies

4 Battelle Memorial Institute Project Management Division 5 D5 King Avenue

Columbus, OH 43201

ATTN: W. A. Carbeiner/

S. H. Basham

J. F. Kircher

W. J. Madia

B. Rawles

F. Holzer

Lawrence Livermore NationaI Laboratory

University of California

P.0. Box 808

Livermore, CA 94550

D. T. OakTey, MS 671

Los Alamos Scientific Laboratory P.0. Box 1663

Los Alamos, NM 87544

T. H. Row

Oak Ridge National Laboratory

P.0. Box X

Oak Ridge, TN 37830

R. T. Jubin

Consolidated Fuel Reprocessing Program

Oak Ridge National Laboratory

P.0. Box X

Oak Ridge, TN 37830

3 Oak Ridge National Laboratory

P.0. Box Y

Oak Ridge, TN 37830

ATTN: J. 0. Blomeke

W. D. Burch

L. A. Dole 
No, of

Copies

5 Sandia Laboratories

P.0. Box 5800

Albuquerque, NM 87185

ATTN: D. R. Anderson

J. F. Ney

R. W. Lynch

W. Weart

Technical Library

B. R. Wheeler

Westinghouse Idaho Nuclear

Co. , Inc.

P.0. Box 4000

Idaho Falls, ID 83401

6 E. I. du Pont de Nemours Company

Savannah River Laboratory

Aiken, SC 29801

ATTN: $M$. D. Boersma

J. G. Glasscock

E. J. Hennelly

J. R. Knight

M. J. Plodinec

C. T. Randall

E. A. Jennrich

EG\&G Idaho

P.0. Box 1625

Idaho Falls, ID 83415

V. Ricks

$E G \& G$

1580 Sawtil]

P.0. Box 1680

Idaho Falls, ID 83415

K. V. Gilbert/P. G. Hagen

Rockwell International

Rocky Flats Plant

P.0. Box 464

Golden, CO 80401

G. W. Meyers

Atomics International Division Rockwell International 8900 DeSoto Avenue

Canoga Park, CA 91304
No. of

Copies

T. H. Pigford

Department of Nuclear

Engineering

University of California

Berke]ey, CA 94720

M. E. Spaeth

Science Applications, Inc.

2769 South Highland

Las Vegas, NV 89109

J. F. Strahl

Weston

2301 Research Boulevard

Third Floor

Rockville, MD 20850

R. Willjams

Electric Power Research Institute

$3412 \mathrm{Hjllview} \mathrm{Avenue}$

P.0. Box 10412

Palo Alto, CA 94304

5 West Valley Nuclear Services Company

P.0. Box 191

West Valley, NY 14171

ATTN: C. C. Chapman

J. C. Cwynar

J. L. Knabenschuh

J. E. Krauss

J. M. Pope

J. W. Bartiett

The Analytic Sciences Corporation

6 Jacob Way

Reading, MA 01867

W. A. Freeby/J. L. Jardine

Bechtel Nationa 7 , Inc.

P.0. Box 3965

San Francisco, CA 94119 
No. of

Copies

Librarian

Westinghouse Electric Corporation

Technical Library

P.0. Box 40039

A]buquerque, NM 87196

L. L. Hench

Department of Materials Science \& Engineering

University of Florida

Gainesville, FL 32611

J. L. Larocca, Chairman

Energy Research \& Development Authority

Empire State Plaza

Albany, NY 12223

R. G. Post

College of Engineering

University of Arizona

Tucson, AZ 85721

\section{ONSITE}

10 DOE Richland Operations Office

J. H. Anttonen

E. A. Bracken

G. J. Bracken

R. D. Izatt

N. T. Karagianes

M. J. Plahuta

J. L. Rhoades

M. W. Shupe

J. 0 . White

C. E. Collantes

10 Rockwell Hanford Operations
A. J. Diliberto
R. N. Gurley
H. E. McGuire
R. D. Prosser
I. E. Reep
J. C. Womack

No. of

Copies

Rockwell Hanford Operations (Continued)

T. B. Venziano

D. D. Wodrich

R. D. Wojtasek

File Copy

UNC United Nuclear Industries

T. E. Dabrowski/W. J. Kyriazis

Westinghouse Hanford Company

R. E. Lerch

21 Pacific Northwest Laboratory

J. R. Divine

M. S. Hanson

P. E. Hart

W. W. Laity

D. B. Mackey (10)

Technical Information (5)

Publishing Coordination (2) 